\title{
KONTRIBUSI HUMAN CAPITAL DAN CUSTOMER CAPITAL DALAM MENGGAPAI KINERJA CAFÉ DAN RESTO DI SURABAYA
}

\author{
Gendut Sukarno ${ }^{1)}$ \\ Lia Nirawati ${ }^{2)}$ \\ ${ }^{1)}$ Dosen FEB UPN"Veteran" Jatim \\ ${ }^{2)}$ Dosen FISIP UPN"Veteran" Jatim \\ sukarnogendut@yahoo.co.id \\ lianirawati@ymail.com
}

\begin{abstract}
ABSTRAKSI
Penilaian kinerja perusahaan berbasis human capital merupakan hal menarik yang perlu dikembangkan oleh perusahaan. Human capital merupakan salah satu komponen utama dari intellectual capital (intangible asset) yang dimiliki perusahaan. Selama ini, penilaian terhadap kinerja perusahaan lebih banyak menggunakan sumber daya yang bersifat fisik (tangible asset). Human capital di dalam organisasi memiliki potensi penuh untuk membangun orientasi pasar bagi konsumennya. Jika kompetensi pegawai di dalam suatu organisasi semakin baik, mereka akan memahami kebutuhan konsumen dan mengembangkan customer capital untuk menahan loyalitas konsumen. Pengelolaan customer capital yang baik akan berdampak terhadap kinerja perusahaan.

Penelitian ini bertujuan untuk mengkaji konsep keterhubungan human capital dan customer capital dan dampaknya terhadap kinerja café dan resto di Surabaya. Populasi dalam penelitian adalah pipinan/ pengelola café dan resto di Surabaya, dengan sampel sebanyak 30 responden. Teknik analisis data yang digunakan adalah PLS (Partial Least Square) yang merupakan metode alternatif analisis dengan Structural Equation Modelling (SEM) yang berbasis variance.

Berdasarkan hasil pengolahan data diketemukan bahwa 1) human capital mampu memberikan kontribusi yang berarti terhadap customer capital. 2) Customer capital mampu memberikan kontribusi yang berarti terhadap kinerja café dan resto di Surabaya, 3) human capital mampu memberikan kontribusi yang berarti terhadap kinerja café dan resto di Surabaya.
\end{abstract}

Kata kunci : human capital, customer capital, kinerja

\section{PENDAHULUAN}

Kafe, yang sering juga disebut coffeehouse, coffee shop, atau café, merupakan istilah yang digunakan untuk tempat yang melayani pesanan kopi atau minuman hangat lainnya. Kafe memiliki karakteristik seperti bar atau restoran, tapi berbeda dengan kafetaria. Banyak kafe yang tidak hanya menyediakan kopi, tetapi juga teh bersama dengan makanan ringan, namun ada juga kafe dan resto yang merupakan kafe yang dilengkapi dengan makanan utama (bukan manakanan ringan). Dari sisi budaya, kafe telah tersebar luas untuk menjadi pusat interaksi sosial dimana orang-orang dapat berkumpul, berbicara, menulis, membaca, melawak, atau sekedar mengisi waktu. 
Masyarakat awalnya mengenal warung kopi sebagai tempat yang relatif sepadan dibandingkan kafe dalam definisi masyarakat barat. Seiring dengan perkembangan zaman, kemajuan teknologi informasi, dan asimilasi budaya barat dan lokal, pengusaha warung kopi berkonsep kafe seperti yang ada di barat mulai menjamur. Muncul banyak kafe baru, mulai dari yang berkonsep terpusat hingga menggunakan sistem waralaba.

Selain Coffezone yang menawarkan konsep waralaba, terdapat juga warung kopi lainnya yang berekspansi secara terpusat. Mulai dari merek internasional seperti Starbucks dan Coffee Bean, hingga merek lokal seperti Excelso dan Ngopi Doeloe menjamur di berbagai wilayah di Indonesia. Pada tahun 2012, permintaan kopi dalam negeri telah mencapai lebih dari 250 ribu ton. Segmen bisnis kedai kopi pun selalu tumbuh lebih dari 10\% dalam beberapa tahun terakhir. Kondisi ini menandakan bahwa bisnis kedai kopi memiliki potensi untuk dimasuki oleh para pelaku usaha. Meskipun begitu, masih terdapat kritik dan kekhawatiran terhadap bisnis kedai kopi.

Pertumbuhan ekonomi yang telah mengerek kesejahteraan warga membuat kinerja para pelaku usaha kafe dan restoran terdongkrak. Kelas menengah yang terus tumbuh menjadi pasar utama kafe dan restoran. Ketua Asosiasi Pengusaha Kafe dan Restoran Indonesia (Apkrindo) Jawa Timur, Tjahjono Haryono, mengatakan, kinerja pebisnis kafe dan restoran selama ini memang ditopang oleh pertumbuhan pusat perbelanjaan yang menyediakan food court. Kelompok kelas menengah adalah pengunjung utama pusat perbelanjaan, yang sekaligus pengunjung utama kafe dan restoran yang terdapat di mal-mal tersebut. "Kalau di Surabaya, ke depan ini akan semakin bagus, ada banyak mal baru yang mempunyai food court cukup besar. Ekonomi warga yang terus naik otomatis akan berpengaruh ke kinerja kafe dan restoran," ujarnya, Minggu (22/5/2011). Dia menilai, prospek bisnis kafe dan restoran di Jatim, khususnya Surabaya, akan sangat bagus.

Untuk mencapai seperti hal di atas diperlukan pelayanan yang prima untuk memberikan kepuasan kepada konsumen café dan resto. Diperlukan human capital (modal insani) yang kokoh dalam pengelolaan café dan resto. Orang sering melihat bisnis café selalu dianggap menguntungkan dengan kelipatan 200\% atau 300\%. Pernyataan demikian memang tidak keliru, namun jangan dikira pencapaiannya dilalui dengan mudah, namun justru sebaliknya. Tidak sedikit bisnis café dan atau resto mengalami kegagalan. Faktor sumber daya manusia yang merupakan modal tidak tampak (tangible assets) merupakan modal yang sangat penting.

Menurut Fattah (2004) “investment in Human Capital” merupakan peletak dasar teori atau konsep modal manusia (human capital). Konsep ini pada intinya menganggap bahwa manusia merupakan suatu bentuk modal atau capital sebagaimana bentuk - bentuk capital lainnya, seperti mesin, teknologi, tanah, uang, dan material. Manusia sebagai human capital tercermin dalam bentuk pengetahuan, gagasan (ide), kreativitas, keterampilan dan produktivitas kerja. Tidak seperti bentuk capital lain yang hanya diperlakukan sebagai tools, human capital ini dapat menginvestasikan dirinya sendiri melalui berbagai bentuk investasi sumber daya manusia, diantaranya pendidikan formal, pendidikan informal, pengalaman kerja, kesehatan dan gizi serta transmigrasi.

Sumber daya manusia atau human capital memiliki lima komponen yaitu individual capability, individual motivation, leadership, the organizational climate dan workgroup effectiveness, (Mayo, 2000). Masing - masing komponen memiliki peranan yang berbeda dalam menciptakan human capital perusahaan yang pada akhirnya menentukan nilai sebuah perusahaan. 
Human capital di dalam organisasi memiliki potensi penuh untuk membangun orientasi pasar bagi konsumennya. Namun demikian selain Human capital yang harus dimiliki perusahaan, terdapat factor lain yang merupakan capital lain yang dapat memberikan kontribusi terhadap kinerja perusahaan yaitu Relational (Customer) capital. Relational (customer) capital merupakan modal untuk menjalin hubungan dengan pihak relasi atau pelanggan perusahaan.

Jika kompetensi pegawai di dalam suatu organisasi semakin baik, mereka akan memahami kebutuhan konsumen dan mengembangkan customer capital untuk menahan loyalitas konsumen. Customer Capital yang kokoh inilah akan menghasilkan pelayanan konsumen yang maksimum. Disamping itu, human capital juga merupakan sumber inovasi da pembaharuan bagi perusahaan.

Hampir setiap bagian dari pengalaman makan di café dan rseto tergantung pada kualitas pelayanan restoran dalam hal sambutan, pemesanan, pelayanan, hingga pembayaran. Di beberapa kasus, makanan yang enak menjadi tidak berarti karena kualitas pelayanan yang buruk. Pengelola harus selalu memperhatikan pelayanan dalam prioritas tertinggi. Pelayanan Restoran yang baik adalah tentang membuat pengunjung merasa betah dengan membuat interaksi yang positif dan menyenangkan antara pengunjung dan staf. Bagaimana hal tersebut dapat dicapainya, sopan dan perhatian saat penyajian, tepat waktu dalam memenuhi kebutuhan pengunjung, pastikan staf café dan resto memiliki pengetahuan tentang menu dan menyajikan makanan dengan sikap yang tepat.

Merujuk uraian di atas penulis ingin mengkaji keterkaitan antara Human Capital, Customer Capital, dan Kinerja Bisnis Café dan Resto di Surabaya.

\section{KERANGKA KONSEPTUAL}

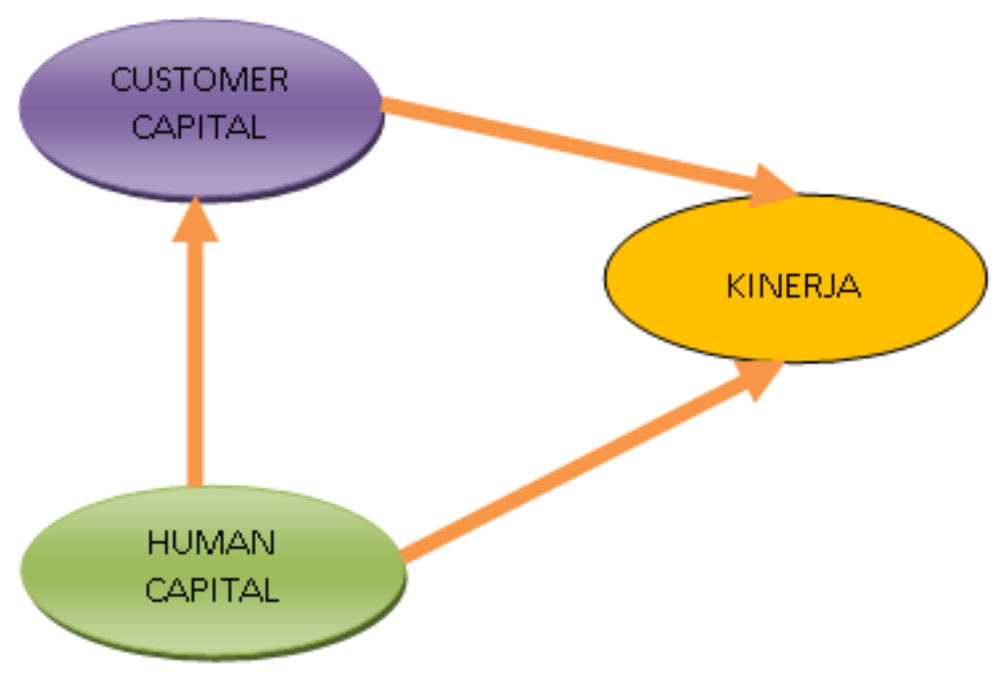

Gambar 2.1. Kerangka Konsep Penelitian 


\section{METODE PENELITIAN}

\subsection{Definisi operasional}

\subsubsection{Human Capital (X1)}

Human capital merupakan kombinasi dari pengetahuan, keterampilan, inovasi dan kemampuan seseorang untuk menjalankan tugasnya, sehingga dapat menciptakan suatu nilai untuk mencapai tujuan (Schermerhon, 2005).

Menurut Mayo (2000) dalam Martina Human capital meliputi lima komponen :

\begin{tabular}{|c|c|}
\hline 1. Individual capability & $\begin{array}{l}\text { a.Knowledge/skill/ experience /network } \\
\text { b.ability to achieve results } \\
\text { c. potential for growth } \\
\begin{array}{l}\text { d. what they bring into work from other parts of } \\
\text { their life }\end{array}\end{array}$ \\
\hline 2.Individual motivation & $\begin{array}{l}\text { a. Aspirations } \\
\text { b. Ambitions and drive } \\
\text { c. work motivations }\end{array}$ \\
\hline 3. Leadership & $\begin{array}{l}\text { a. The clarity of vision of top management and the- } \\
\text { iability to communicate it and behave in a way tha- } \\
\text { tis consistent with it }\end{array}$ \\
\hline $\begin{array}{l}\text { 4. The organizational cli- } \\
\text { mate }\end{array}$ & $\begin{array}{l}\text { a. The culture of the organization } \\
\text { b. especially in its freedom to innovate } \\
\text { c. openness } \\
\text { d. flexibility } \\
\text { e. respect for the individual }\end{array}$ \\
\hline 5. Workgroup Effectiveness & $\begin{array}{l}\text { a. Supportiveness } \\
\text { b. mutual respect }\end{array}$ \\
\hline
\end{tabular}




\subsubsection{Customer Capital (X2)}

\begin{tabular}{|l|l|}
\hline $\begin{array}{l}\text { Customer capital merupakan hubungan baik } \\
\text { antara perusahaan dengan customer atau relasi } \\
\text { sehingga mendukung perkembangan bisnis pe- } \\
\text { rusahaan tersebut (Edvinsson yang dikutip oleh } \\
\text { (Brinker 2000) pengukuran customer capital, }\end{array}$ & 1. Customer profile. \\
\hline & 2. Customer duration \\
\hline & 3. Customer Role \\
\hline & 4. Customer support \\
\hline
\end{tabular}

\subsubsection{Kinerja Café dan Resto ( $\mathrm{Y}$ )}

\begin{tabular}{|l|l|}
\hline $\begin{array}{l}\text { Kinerja Café dan Resto sebagai gambaran } \\
\text { mengenai tingkat pencapaian pelaksanaan tugas } \\
\text { dalam suatu organisasi Café dan Resto dalam } \\
\text { upaya mewujudkan sasaran, tujuan, visi, dan } \\
\text { misi organisasi Café dan Resto tersebut. }\end{array}$ & 1. input \\
\hline & 2. outputs \\
\hline & 3. outcomes \\
\hline & 4. benefit \\
\hline & 5.Impacts \\
\hline
\end{tabular}

\subsection{Populasi dan Sampel}

Populasi dalam penelitian ini adalah para pengelola/pemilik café dan resto di Surabaya, dengan sampel sebanyak 30 responden. Sampel kecil tersebut sesuai sebagaimana teknik analisis data yang digunakan adalah PLS (Partial Least Square) yang tidak mengharuskan sampel besar.

\subsection{Teknik Analisis}

Teknik analisis data yang digunakan pada penelitian ini adalah dengan menggunakan Partial Least Sequare (PLS). PLS menurut Wold H (1982) merupakan metode analisis yang powerfull oleh karena tidak didasarkan banyak asumsi. Metode PLS mempunyai keunggulan tersendiri diantaranya: data tidak harus berdistribusi normal multivariate (indikator dengan skala kategori, ordinal, interval sampai rasio dapat digunakan pada model yang sama) dan ukuran sampel tidak harus besar. 


\section{HASIL dan PEMBAHASAN}

4.1. Hasil Penelitian

\subsubsection{Uji Validitas}

- Pengujian Outer Model

- First Order (Model Pengukuran Variabel dengan Dimensi)

Tabel 4.1 First Order

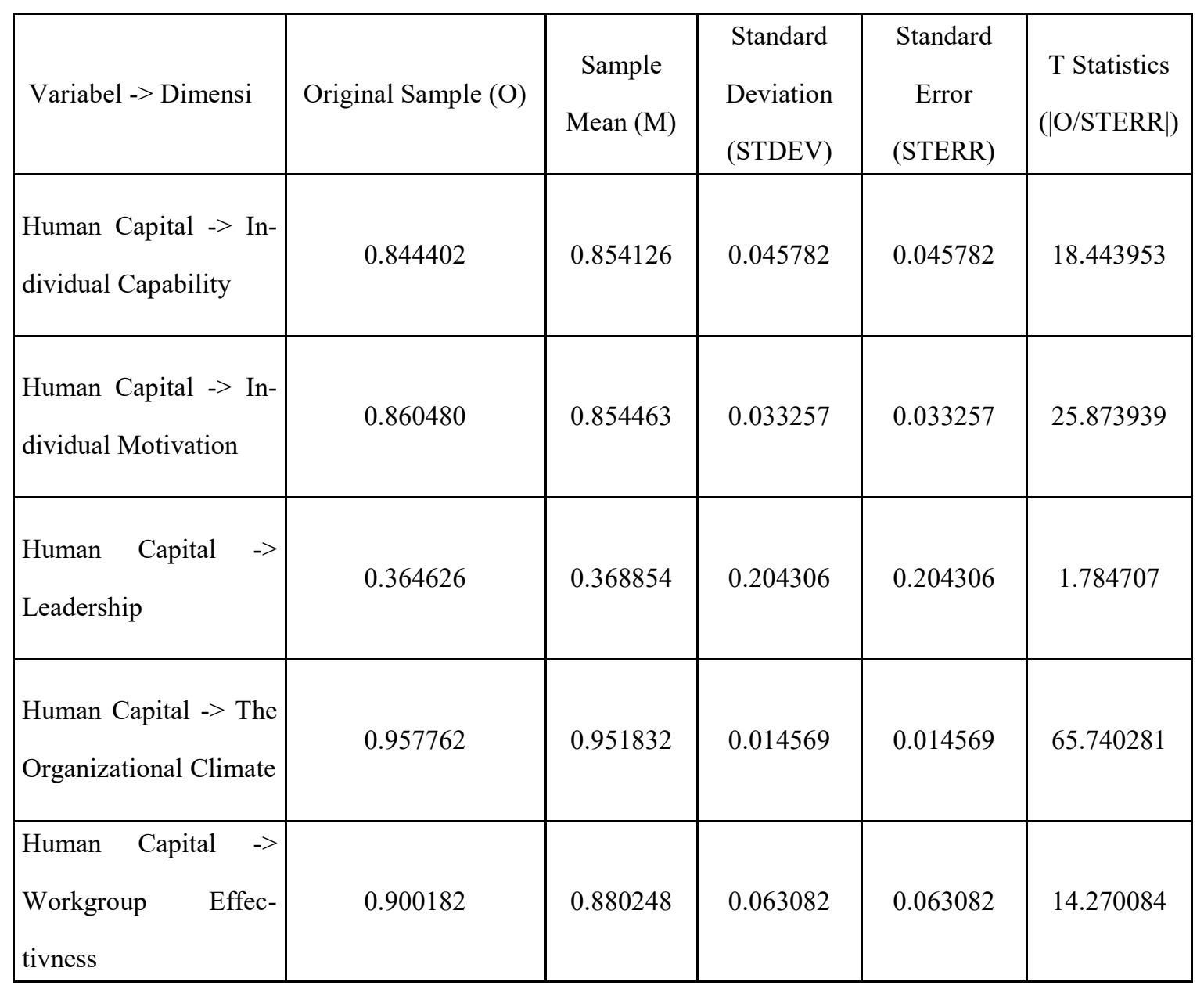

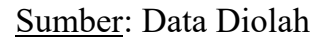

Model variabel Human Capital dengan dimensi dengan bentuk reflektip pada dasarnya merupakan hubungan regresi variable ke dimensi, maka cara menilainya adalah dengan melihat nilai koefisien regresi dan signifikansi dari koefisien regresi tersebut. Hasil pengujian pada tabel inner weight menunjukkan bahwa seluruh dimensi pada variabel Human Capital memiliki korelasi dengan dimensinya secara signifikan karena nilai T-Statistiknya lebih besar dari 1,645 (pada $\mathrm{Z} \alpha=0,10$ ). Jadi dapat disimpulkan bahwa seluruh dimensi tersebut sebagai pengukur variable Human Capital. 
- Second Order (Model Pengukuran Dimensi dengan Indikator)

Tabel 4.2 Outer Loadings (Mean, STDEV, T-Values)

\begin{tabular}{|c|c|c|c|c|c|}
\hline & $\begin{array}{l}\text { Factor Loading } \\
\text { (O) }\end{array}$ & $\begin{array}{l}\text { Sample Mean } \\
\text { (M) }\end{array}$ & $\begin{array}{l}\text { Standard } \\
\text { Deviation } \\
\text { (STDEV) }\end{array}$ & $\begin{array}{l}\text { Standard Error } \\
\text { (STERR) }\end{array}$ & $\begin{array}{c}\text { T Statistics }(\mid \mathrm{O} / \\
\text { STERR } \mid)\end{array}$ \\
\hline $\mathrm{X} 1.1 .1<-$ Individual Capability & 0.795334 & 0.785809 & 0.073748 & 0.073748 & 10.784540 \\
\hline $\mathrm{X} 1.1 .2<-$ Individual Capability & 0.612821 & 0.590907 & 0.121503 & 0.121503 & 5.043674 \\
\hline $\mathrm{X} 1.1 .3<-$ Individual Capability & 0.621648 & 0.599179 & 0.126355 & 0.126355 & 4.919843 \\
\hline $\mathrm{X} 1.1 .4<-$ Individual Capability & 0.448266 & 0.461048 & 0.115923 & 0.115923 & 3.866929 \\
\hline $\mathrm{X} 1.2 .1<$ - Individual Motivation & -0.652508 & -0.447726 & 0.491317 & 0.491317 & 1.328078 \\
\hline $\mathrm{X} 1.2 .2<$ - Individual Motivation & -0.475745 & -0.282966 & 0.548282 & 0.548282 & 0.867702 \\
\hline $\mathrm{X} 1.2 .3<$ - Individual Motivation & -0.142864 & -0.035331 & 0.402273 & 0.402273 & 0.355141 \\
\hline X1.2.4<- Individual Motivation & 0.791064 & 0.726547 & 0.151026 & 0.151026 & 5.237927 \\
\hline X1.3<- Leadership & 1.000000 & 1.000000 & 0.000000 & & \\
\hline $\mathrm{X} 1.4 .1<-$ The Organizational Climate & 0.747719 & 0.748269 & 0.070088 & 0.070088 & 10.668279 \\
\hline $\mathrm{X} 1.4 .2<-$ The Organizational Climate & 0.273273 & 0.275854 & 0.189929 & 0.189929 & 1.438814 \\
\hline $\mathrm{X} 1.4 .3<-$ The Organizational Climate & 0.701746 & 0.691604 & 0.071905 & 0.071905 & 9.759412 \\
\hline X1.4.3<- Human Capital & 0.638729 & 0.623968 & 0.088437 & 0.088437 & 7.222426 \\
\hline X1.4.4<- The Organizational Climate & 0.602209 & 0.577284 & 0.143920 & 0.143920 & 4.184340 \\
\hline $\mathrm{X} 1.4 .5<-$ The Organizational Climate & 0.925093 & 0.918843 & 0.021879 & 0.021879 & 42.282985 \\
\hline X1.5.1<- Workgroup Effectivness & 0.925578 & 0.928180 & 0.016609 & 0.016609 & 55.728425 \\
\hline X1.5.2<- Workgroup Effectivness & 0.842966 & 0.846551 & 0.020540 & 0.020540 & 41.040921 \\
\hline X1.5.3<- Workgroup Effectivness & 0.831620 & 0.833212 & 0.052845 & 0.052845 & 15.736874 \\
\hline X2.1<- Customer Capital & 0.881287 & 0.866147 & 0.048875 & 0.048875 & 18.031473 \\
\hline X2.2<- Customer Capital & 0.819792 & 0.813805 & 0.049151 & 0.049151 & 16.678994 \\
\hline X2.3<- Customer Capital & -0.290124 & -0.256262 & 0.252028 & 0.252028 & 1.151155 \\
\hline X2.4<- Customer Capital & 0.920736 & 0.915779 & 0.025481 & 0.025481 & 36.133580 \\
\hline Y1 <- Kinerja Perusahaan & -0.235929 & -0.190988 & 0.218932 & 0.218932 & 1.077636 \\
\hline Y2<- Kinerja Perusahaan & 0.145443 & 0.195753 & 0.266159 & 0.266159 & 0.546450 \\
\hline Y3 <- Kinerja Perusahaan & 0.954667 & 0.882811 & 0.121648 & 0.121648 & 7.847798 \\
\hline Y4 <- Kinerja Perusahaan & 0.721207 & 0.683692 & 0.155220 & 0.155220 & 4.646357 \\
\hline Y5 <- Kinerja Perusahaan & 0.010493 & 0.012871 & 0.265680 & 0.265680 & 0.039493 \\
\hline
\end{tabular}

\section{Sumber: Data Diolah}

Berdasarkan pada tabel outer loading di atas, pada variabel dengan indikator reflektif yaitu seluruh dimensi pada variabel Human Capital (Individual Capability, Leadership, The Organizational Climate dan Workgroup Effectivness) serta pada Customer Capital dan Kinerja perusahaan tidak seluruh indikator memiliki factor loading (original sample estimate) lebih besar dari 0,50 dan atau signifikan (Nilai T-Statistic 
lebih besar dari nilai $\mathrm{Z} \alpha=0,10(10 \%)=1,645)$, sehingga tidak seluruh indikator tersebut menjadi pengukur/ indikator variabelnya atau dimensinya karena ada beberapa diantara indikator diatas yang nilai factor loading masih dibawah 0,50. Hanya indikator yang memiliki nilai factor loading (original sample estimate) lebih besar dari 0,50 dan atau signifikan (Nilai T-Statistic lebih besar dari nilai $\mathrm{Z} \alpha=0,10(10 \%)=1,645$ ) yang memenuhi Convergen vailidity dan validitasnya baik.

\section{- Average Variance Extracted (AVE)}

Tabel 4.3 Average variance extracted (AVE)

\begin{tabular}{|l|c|}
\hline & AVE \\
\hline Customer Capital & 0.595163 \\
\hline Human Capital & 0.350687 \\
\hline Kinerja Perusahaan & 0.301691 \\
\hline
\end{tabular}

Sumber: Data Diolah

Model Pengukuran berikutnya adalah nilai Avarage Variance Extracted (AVE), yaitu nilai menunjukkan besarnya varian indikator yang dikandung oleh variabel latennya. Hasil pengujian menunjukkan bahwa nilai AVE untuk variabel Human Capital sebesar 0.350687 dan nilai AVE untuk variabel Kinerja Perusahaan sebesar 0.301691 atau kedua variabel tersebut nilai AVE dibawah 0,7 sehingga validitasnya kurang baik, sedangkan untuk variabel Customer Capital nilai AVEnya sebesar 0.595163 atau lebih besar dari 0,5 sehingga Customer Capital tersebut dikatakan valid.

\subsubsection{Uji Reliabilitas}

\subsubsection{Composite Reliability}

Composite Reliability adalah indeks yang menunjukkan sejauh mana suatu alat pengukur dapat dipercaya untuk diandalkan. Hasil selengkapnya dapat dilihat dalam tabel berikut :

Tabel 4.4. Composite Reliability

\begin{tabular}{|l|c|}
\hline & Composite Reliability \\
\hline Customer Capital & 0.770505 \\
\hline Human Capital & 0.851133 \\
\hline Kinerja Perusahaan & 0.421775 \\
\hline
\end{tabular}

Sumber: Data Diolah

Reliabilitas konstruk yang diukur dengan nilai composite reliability, konstruk reliabel jika nilai composite reliability di atas 0,70 maka indikator disebut konsisten dalam mengukur variabel latennya. Hasil pengujian menunjukkan bahwa konstruk (variabel) Kinerja Perusahaan memiliki nilai composite reliability sebesar 0.421775 atau lebih kecil dari 0,7 sehingga dikatakan kurang reliabel, namun pada variabel Customer 
Capital nilai composite reliability sebesar 0.770505 dan variabel Human Capital nilai composite reliability sebesar 0.851133 atau kedua variabel tersebut memiliki nilai Composite reliabiliy lebih besar dari 0,7 sehingga variabel tersebut bisa dikatakan reliabel.

\subsubsection{Pengujian Inner Model}

Pengujian terhadap model struktural dilakukan dengan melihat nilai R-Square yang merupakan uji goodness-fit model. Pengujian inner model dapat dilihat dari nilai R-square pada persamaan antar variabel latent. Nilai $\mathrm{R}^{2}$ menjelaskan seberapa besar variabel eksogen (independen/bebas) pada model mampu menerangkan variabel endogen (dependen/terikat).

Tabel 4.5 R-Square

\begin{tabular}{|l|c|}
\hline & R Square \\
\hline Customer Capital & 0.751890 \\
\hline Human Capital & \\
\hline Kinerja Perusahaan & 0.458278 \\
\hline
\end{tabular}

Sumber: Data Diolah

Berdasarkan tabel di atas menunjukkan bahwa Nilai $\mathrm{R}^{2}=1-(1-0,751890)(1-0,458278)=$ 0.86559. Hal ini dapat diinterpretasikan bahwa model mampu menjelaskan fenomena Kinerja Perusahaan sebesar 86,56\%. Sedangkan sisanya (13,44\%) dijelaskan oleh variabel lain (selain Human Capital dan Customer Capital) yang belum masuk ke dalam model dan error. Artinya Kinerja Perusahaan dipengaruhi oleh Human Capital dan Customer Capital sebesar 86,56\% sedang sebesar 13,44\% dipengaruhi oleh variabel selain Human Capital dan Customer Capital. 


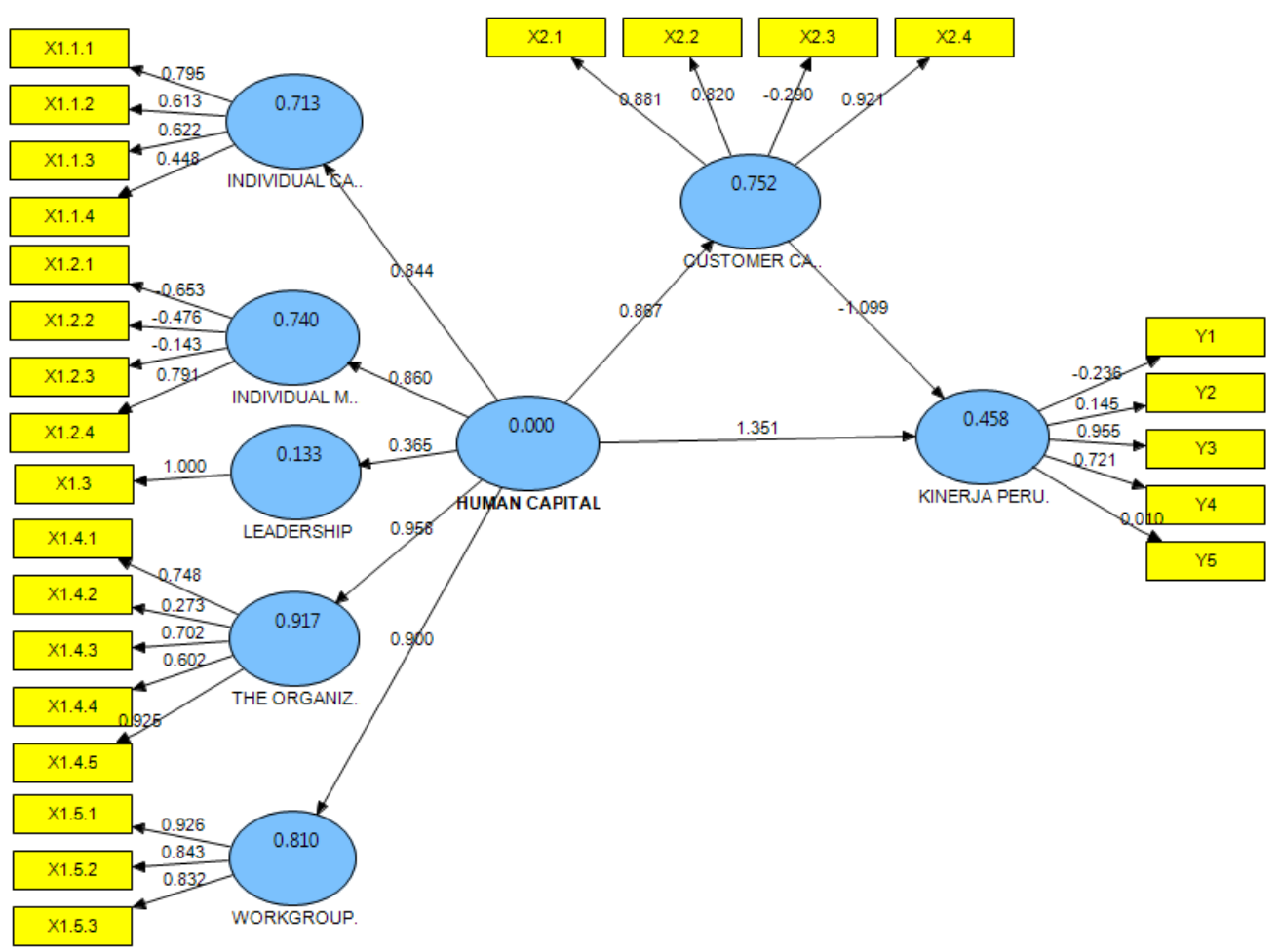

Gambar 4.1 PLS Model Konseptual dengan Nilai Path Koefisien

Berdasarkan gambar di atas dapat dilihat nilai-nilai dari indikator terhadap variabel laten, sehingga dapat diketahui indicator Kinerja Perusahaan adalah indikator yang paling berpengaruh terhadap variabel laten. Berikut adalah tabel tentang hasil inner weight (uji kausalitas):

Tabel 4.6 Inner Weight

\begin{tabular}{|l|l|l|l|l|l|}
\hline & $\begin{array}{c}\text { Path Coeffi- } \\
\text { cient (O) }\end{array}$ & $\begin{array}{c}\text { Sample } \\
\text { Mean (M) }\end{array}$ & $\begin{array}{c}\text { Standard } \\
\text { Deviation } \\
(\text { STDEV) }\end{array}$ & $\begin{array}{c}\text { Standard } \\
\text { Error } \\
(\text { STERR })\end{array}$ & $\begin{array}{c}\text { T Statistics } \\
(\mid \mathrm{O} / \text { STERR } \mid)\end{array}$ \\
\hline $\begin{array}{l}\text { Human Capital -> } \\
\text { Customer Capital }\end{array}$ & 0.867116 & 0.868598 & 0.028414 & 0.028414 & 30.517538 \\
\hline $\begin{array}{l}\text { Customer Capital -> } \\
\text { Kinerja Perusahaan }\end{array}$ & -1.098501 & -0.988086 & 0.442665 & 0.442665 & 2.481560 \\
\hline $\begin{array}{l}\text { Human Capital -> } \\
\text { Kinerja Perusahaan }\end{array}$ & 1.351128 & 1.292290 & 0.322176 & 0.322176 & 4.193758 \\
\hline & & & & & \\
\hline
\end{tabular}


Berdasarkan tabel di atas diperoleh :

- Human Capital berpengaruh terhadap Customer Capital dengan koefisien path sebesar 0,867116, dapat diterima, dimana nilai T-Statistic $=30,517538$ lebih besar dari nilai $\mathrm{Z} \alpha=0,10(10 \%)=1,645$, maka Signifikan (Positif).

- Customer Capital berpengaruh terhadap Kinerja Perusahaan dengan koefisien path sebesar -1,098501, dapat diterima, dimana nilai T-Statistic $=2,481560$ lebih besar dari nilai $\mathrm{Z} \alpha=0,10(10 \%)=1,645$, maka Signifikan (Negatif)

- Human Capital berpengaruh terhadap Kinerja Perusahaan dengan koefisien path sebesar 1,351128, dapat diterima, dimana nilai $\mathrm{T}$-Statistic $=4,193758$ lebih besar dari nilai $\mathrm{Z} \alpha=0,10(10 \%)=1,645$, maka Signifikan (Positif)

\subsection{PEMBAHASAN}

\subsubsection{Pengaruh Human Capital Terhadap Customer Capital}

Berdasarkan hasil penelitian yang telah dilakukan diperoleh hasil bahwa Human Capital berpengaruh terhadap Customer Capital. Hal tersebut mengandung makna bahwa Human Capital pada café dan resto di Surabaya benar-benar mempunyai kontribusi terhadap Customer Capital. Fenomena tersebut mengindikasikan modal insani yang bagus pada café dan resto baik dalam Individual capability, Individual motivation, Leadership, The organizational climate, Workgroup Effectiveness. Dengan kokohnya ke 5 dimensi yang ada pada human capital akan meningkatkan Customer Capital yang dimiliki café dan resto di Surabaya, baik dalam hal Customer profile, Customer duration,

Customer Role, Customer support.

Temuan di atas selaras dengan hasil penelitian dari Bontis et.al. (2000) serta Astuti dan Sabeni (2005). Mereka menyatakan dengan tacit knowledge-nya human capital mampu menciptakan nilai (value creation) yaitu customer capital bagi perusahaan. Astuti dan Sabeni (2005), yang berpendapat bahwa Customer Capital dan Structural Capital dapat berfungsi sebagai variabel intervening hubungan human capital dan business performance, sedangkan structural capital dapat digunakan untuk memediasi hubungan customer capital dan business performance.

\subsubsection{Pengaruh Customer Capital Terhadap Kinerja Perusahaan}

Berdasarkan hasil penelitian yang telah dilakukan diperoleh hasil bahwa Customer Capital berpengaruh terhadap kinerja perusahaan dengan arah hubungan terbalik. Hal tersebut mengandung makna bahwa customer capital pada café dan resto di Surabaya benar-benar mempunyai kontribusi terhadap kinerja perusahaan namun dengan arah hubungan tidak searah. Fenomena ini mengandung makna perubahan peningkatan Customer Capital tidak diikuti perubahan peningkatan terhadap kinerja café dan resto di Surabaya. Customer capital yang bagus tersebut tercermin dari kuatnya Customer profile, Customer duration, Customer Role, Customer support yang dimiliki café dan resto di Surabaya, namun justru belum dapat memberikan efek perubahan terhadap meningkatnya kinerja café dan resto di Surabaya.

Kondisi di lapangan menunjukkan bahwa meskipun partner bervariasi tidak mempengaruhi kinerja perusahaan yang baik pula sehingga menjadikan kinerja perusahaan berfluktuasi. Oleh karena itu hal tersebut 
menyebabkan pengelolaan customer capital tidak dipentingkan dan berpengaruh secara tidak langsung terhadap kinerja perusahaan. Temuan diatas tidak sesuai dengan hasil penelitian oleh Bontis (1998), yang berpendapat bahwa customer capital berpengaruh signifikan terhadap business performance.

\subsubsection{Pengaruh Human Capital Terhadap Kinerja Perusahaan}

Berdasarkan hasil penelitian yang telah dilakukan diperoleh hasil bahwa Human Capital berpengaruh terhadap kinerja perusahaan. Hal tersebut mengandung makna bahwa Human Capital pada café dan resto di Surabaya benar-benar mempunyai kontribusi terhadap kinerja café dan resto di Surabaya . Fenomena tersebut mengindikasikan modal insani yang bagus pada café dan resto baik dalam Individual capability, Individual motivation, Leadership, The organizational climate, Workgroup Effectiveness. Kokohnya human capital yang dimiliki akan berdampak terhadap meningkatnya kinerja café dan resto yang tercermin dalam indicator : input, outputs, outcomes, benefit dan Impacts

Temuan diatas sesuai dengan hasil penelitian dari Pulic (1998), Bontis (1998) Divianto (2010), yang berpendapat bahwa human capital berpengaruh signifikan terhadap business performance.

\section{DAFTAR PUSTAKA}

Anatan, Lina." Kualitas pelayanan (service) quality) : strategi meraih keunggulan kompetitif berkelanjutan melalui customer satisfaction.” Jurnal Ekonomi Bisnis dan Koperasi 5, No.2 (2003) : 62-76.

Astuti, Partiwi Dwi. 2005. "Hubungan Intellectual Capital dan Business Performance." Jurnal MAKSI. Vol 5, 34-58.

Burr, R. and Girardi, A. 2002. "Intellectual Capital: More than the Interaction of Competence x Commitment" dalam Australian Journal of Management, Vol, 27.

Divianto (2010).” Pengaruh factor - factor Intellectual Capital (human capital, structural capital dan customer capital) terhadap business performance”. Jurnal Ilmiah Orasi Bisnis, Edisi IV.

Fattah, Nanang (2004).”Ekonomi dan Pembiayaan Pendidikan”. Bandung, Remaja Rosdakarya.

Fitz-enz, J, 2000. The ROI of Human Capital: Measuring the Economic Value Added of Employee Performance. AMA-COM, American Management Association, New York.

Juwita, Anggraini (2007). "Pengaruh Human Capital terhadap Bussiness Performance melalui Customer Capital". Vol.4, no.2.

Martina D.P. A. Ongkorahardjo, Antonius Susanto, Dyna Rachmawati. 2008. Analisis Pengaruh Human Capital Terhadap Kinerja Perusahaan (Studi Empiris pada Kantor Akuntan Publik di Indonesia). Jurnal Akuntansi dan Keuangan, Vol. 10, No. 1. 
Mayo, A., 2000. "The Role of Employee Development in The Growth of Intellectual Capital”, Personal Review, Vol. 29, No. 4.

Sawarjuwono, T., dan A. P. Kadir. 2003. ’Intellectual Capital: Perlakuan, Pengukuran dan Pelaporan”, Jurnal Akuntansi dan Keuangan Vol.5, No.1, Mei: 35-57.

Schermerhon. 2005. Management, 8th edition. John Wiley \& Sons, Inc, USA.

Sedarmayanti. 2007. Manajemen Sumber Daya Manusia, Reformasi Birokrasi dan Manajemen Pegawai Negeri Sipil. Bandung : PT. Refika Aditama.

Starttovic, D. and Marr, B. 2004. “Understanding Corporate Value: managing and Reporting Intellectual Capital”. Chartered Institute of Management Accountants.

Totanan, C., 2004. "Peranan Intellectual Capital dalam Penciptaan Nilai untuk Keunggulan Bersaing", Usahawan, No. 1, Tahun XXXIII,Januari: 27-31.

Weatherly, L.A. 2003. "The Value of People: The Challenges and Opportunities of Human Capital Measurement and Reporting," dalam Research Quarterly. Society for Human Resource Management.

Wibowo. 2007. Manajemen Kinerja. Jakarta : PT. Raja Grafindo Persada.

Wold H. (1982). Soft modeling : the basic desing and some extensions, In : System under indirect observation, part 2, Joreskog K.G., Wold H (eds). North - Holland, 1 -5.

Wright, P.M., Dunford, B.B., \& Snell, S.A. 2001. Human resources and the resourcebased view of the firm. Journal of Management, 27: 701-721. 